\title{
Pengaruh Tujuan Anggaran Terhadap Perilaku, Sikap, dan Kinerja Aparat Pemerintah Daerah di Kabupaten Minahasa
}

\author{
Oleh: \\ I Gede Suwetja \\ Fakultas Ekonomi dan Bisnis \\ Universitas Sam Ratulangi Manado \\ Email: gedesuwetja1@hotmail.com
}

\begin{abstract}
ABSTRAK
Penelitian ini menggunakan dua pendekatan yaitu Pendekatan Kuantitatif dan Pendekatan Kualitatif. Untuk mendapatkan pemahaman yang lebih mendalam dibalik pengaruh karakteristik tujuan anggaran terhadap perilaku, sikap, dan kinerja aparat pemerintah daerah Kabupaten Minahasa, maka dilengkapi dengan telaah kualitatif. Pendekatan kualitatif dalam penelitian ini akan menggunakan metode kombinasi (triangulation) dengan alat analisisnya adalah fenomenologi. Penelitian ini berusaha ingin mengetahui apakah karakteristik tujuan berpengaruh terhadap perilaku, sikap, dan kinerja aparat pemerintah daerah Kabupaten Minahasa dalam menyusun anggaran, melaksanakan anggaran, dan pertanggungjawaban anggaran. Penelitian ini menemukan bahwa karakteristik tujuan anggaran secara simultan berpengaruh secara positif terhadap perilaku, sikap, dan kinerja aparat pemerintah daerah Kabupaten Minahasa dengan nilai $\mathrm{F}_{\text {hitung }}>$ $\mathrm{F}_{\text {tabel. }}$ Hal ini menunjukkan bahwa perilaku, sikap, dan kinerja aparat pemerintah daerah Kabupaten Minahasa dalam penyusunan, pelaksanaan, dan pertanggungjawaban anggaran telah mengikuti aturan yang ditetapkan yaitu keikutsertaan staf dan masyarakat baik dalam menyusun, melaksanakan, dan pertanggungjawaban anggaran. Telaahan kualitatif mendukung hasil temuan analisis kuantitatif.
\end{abstract}

Kata kunci: karakteristik tujuan anggaran, perilaku, sikap, dan kinerja

\section{ABSTRACT}

The objective by conducting qualitative approach is to get more comprehensive of understanding about the effect of the characteristics of budget target towards behavior, attitude, and the performance of civil servants in Minahasa Regency to perform budgeting, realize the budget, and hold the responsible for realized budget. The qualitative approach in this study is conduct triangulation method with phenomenology. This study find, the characteristics of budget target simultaneously have positive effect towards behavior, attitude, and performance of civil servants in Minahasa Regency with counted $F$ value higher than table $F$ value. It means, behavior, attitude, and performance in preparing the budget, realize the budget, and hold the responsible for the budget are following the rules, where the participative by community and the servants have been included. The results by quantitative approach are supported by qualitative approach.

Keywords: characteristics of budget target, behavior, attitude, and performance 


\section{PENDAHULUAN}

\subsection{Latar Belakang}

Pemberlakuan Undang-Undang Nomor 32 Tahun 2004 tentang pemerintah daerah dan Undang-Undang Nomor 33 Tentang perimbangan keuangan antara Pusat dan Daerah, membawa perubahan fundamental dalam hubungan Tata Pemerintah dan Hubungan Keuangan, sekaligus membawa perubahan penting dalam pengelolaan Anggaran Daerah. Anggaran Pendapatan dan Belanja Daerah (APBD) disusun berdasarkan pendekatan kinerja, yaitu suatu sistem anggaran yang mengutamakan upaya pencapaian hasil kerja atau ouput dari perencanaan alokasi biaya atau input yang ditetapkan (PP Nomor 58 Tahun 2005). Berdasarkan pendekatan kinerja, APBD disusun berdasarkan pada sasaran tertentu yang hendak dicapai dalam satu tahun anggaran. Oleh karena itu, dalam rangka menyiapkan Rancangan APBD, Pemerintah Daerah bersama DPRD menyusun Kebijakan Umum APBD yang memuat petunjuk dan ketentuan-ketentuan umum yang disepakati sebagai pedoman dalam penyusunan APBD. Penyusunan Kebijakan Umum APBD pada dasarnya merupakan upaya pencapaian visi, misi, tujuan dan sasaran yang telah ditetapkan dalam Rencana Pembangunan Jangka Menengah Daerah (RPJMD) untuk jangka waktu 5 (lima) tahun dan program kepala daerah yang penyusunannya berpedoman kepada RPJPD dengan memperhatikan Rencana Pembangunan Jangka Menengah Nasional (RPJMN) dan standar pelayanan minimal yang telah ditetapkan pemerintah.

Untuk mengantisipasi adanya perubahan lingkungan, pemerintah daerah perlu melakukan penjaringan aspirasi masyarakat untuk mengidentifikasi perkembangan kebutuhan dan keinginan masyarakat. Penjaringan aspirasi masyarakat dimaksudkan untuk memberikan kesempatan kepada masyarakat untuk berpartisipasi dan terlibat dalam proses penganggaran daerah.

\subsection{Perumusan Masalah}

Atas dasar latar belakang tersebut dan beberapa hasil penelitian sebelumnya, maka masalah yang hendak dijawab melalui penelitian ini adalah:

1. Apakah faktor kinerja berpengaruh terhadap karakteristik tujuan anggaran pemerintah daerah.

2. Apakah faktor sikap berpengaruh terhadap karakteristik tujuan anggaran pemerintah daerah.

3. Apakah faktor prilaku berpengaruh terhadap kaqrakteristik tujuan anggaran pemerintah daerah.

\subsection{Tujuan Penelitian}

Untuk menganalisis pengaruh faktor-faktor sikap, prilaku dan kinerja aparat pemerintah daerah kabupaten Minahasa.

\subsection{Manfaat Penelitian}

Diharapkan dengan penelitian ini bagi instansi pemerintah dapat memperoleh masukan khususnya bagi manajemen pemerintah untuk melihat keadaan instansi mereka saat ini sekiranya ada hubungan dengan kinerja.

Bagi penyusun penelitian dan pengguna lainnya kiranya dapat menggunakan hasil karya ilmiah ini maupun teori-teorinya untuk melengkapi sesuai dengan kebutuhannya.

\section{TINJAUAN PUSTAKA}

\subsection{Konsep Penganggaran Daerah}

Untuk dapat menghasilkan struktur anggaran yang sesuai dengan harapan dan kondisi normatif maka APBD yang pada hakikatnya merupakan penjabaran kuantitatif dari tujuan dan sasaran pemerintah daerah serta tugas pokok dan fungsi unit kerja harus disusun dalam struktur yang berorientasi pada pencapaian tingkat kinerja tertentu. Artinya, APBD harus mampu memberikan gambaran yang jelas tentang tuntutan besarnya pembiayaan atas berbagai sasaran yang hendak dicapai, tugas-tugas dan fungsi pokok sesuai dengan kondisi, potensi, aspirasi dan kebutuhan riil di masyarakat untuk suatu tahun tertentu. Dengan 
demikian alokasi dana yang digunakan untuk membiayai berbagai program dan kegiatan dapat memberikan manfaat yang benar-benar dirasakan masyarakat dan pelayanan yang berorientasi pada kepentingan publik (PP No 58 Tahun 2005)

\subsection{Mekanisme Penyusunan APBD}

Dalam menyusun anggaran tahunan, mekanisme dan proses penjaringan informasi pada dasarnya merupakan bagian dari upaya pencapaian visi, misi, tujuan, dan sasaran yang telah ditetapkan dalam rencana strategis daerah. Namun demikian, dalam proses ini kebijakan anggaran harus dijadikan payung bagi eksekutif khususnya unit kerja dalam menyusun kebijakan anggaran tahunan. Dalam penyusunan rencana kerja masing-masing program harus sudah memuat secara lebih rinci uraian mengenai nama program, tujuan dan sasaran program output yang akan dihasilkan, sumber daya yang dibutuhkan, periode pelaksanaan program, lokasi dan indikator kinerja. Seluruh program yang telah dirancang oleh masing-masing unit kerja, selanjutnya diserahkan ke Panitia Eksekutif. Panitia eksekutif selanjutnya menganalisis dan bila perlu menyeleksi program-program yang akan dijadikan rencana kerja di masingmasing unit kerja berdasarkan program kerja yang masuk ke Panitia Eksekutif, selanjutnya disusun dan dirancang draf Kebijakan Pembangunan Dan Kebijakan Anggaran Tahunan (APBD) yang nantinya akan dibahas dengan pihak Legislatif (Kepmendagri No 29 Tahun 2002).

\subsection{Karakteristik Tujuan Anggaran}

Dalam UU No. 17 Tahun 2003 dijelaskan bahwa sebagai instrumen kebijakan ekonomi, anggaran berfungsi untuk mewujudkan pertumbuhan dan stabilitas perekonomian serta pemerataan pendapatan dalam rangka mencapai tujuan bernegara. Dalam upaya untuk meluruskan kembali tujuan dan fungsi anggaran tersebut perlu dilakukan pengaturan secara jelas peran DPR/DPRD dan pemerintah dalam proses penyusunan dan penetapan anggaran sebagai penjabaran aturan pokok yang telah ditetapkan dalam UUD' 45. Sehubungan dengan itu, dalam undang-undang ini disebutkan bahwa belanja negara/daerah dirinci sampai dengan unit organisasi, fungsi, program, kegiatan dan jenis belanja. Hal tersebut berarti bahwa setiap pergeseran anggaran antar unit organisasi, antar kegiatan, dan antar jenis belanja harus mendapat persetujuan DPR/DPRD.

Kajian teoritis sebagai dasar dalam penelitian ini masih banyak menggunakan kajian teoritis pada sektor privat yang berhubungan dengan variabel-variabel yang diteliti. Hal ini dilakukan karena variabel-variabel yang diteliti masih menggunakan dengan variabel penelitian pada sektor privat. Namun tidak mengurangi kajian-kajian teoritis yang berhubungan dengan sektor publik sebagai dasar dalam mendukung penelitian ini. Adapun lima Budgetary Goal Characteristics (Kenis 1979) adalah sebagai berikut:

\subsubsection{Partisipasi Anggaran}

Partisipasi anggaran menunjukkan pada luasnya partisipasi bagi aparat pemerintah daerah dalam memahami anggaran yang diusulkan oleh unit kerjanya dan pengaruh tujuan pusat pertanggungjawaban anggaran mereka.

Aimee \& Carol (2004) menemukan mekanisme input partisipasi warga negara mempunyai pengaruh langsung pada keputusan anggaran. Keuntungan penggu-naan input warga negara ke dalam operasional kota bisa membantu dewan dalam menja-lankan tanggung jawabnya untuk mewakili konstituen dan memberikan visi dan arahan kebijakan jangka panjang. Maryanti (2002) menemukan bahwa partisipasi anggaran tidak berpengaruh terhadap perilaku, sikap dan kinerja. Hal ini menunjukkan bahwa perilaku, sikap, dan kinerja aparat pemerintah daerah tidak dipengaruhi oleh partisipasi anggaran baik dalam menyiapkan usulan anggaran, pelaksanaan anggaran maupun dalam mempertanggung jawabkan anggaran.

\subsubsection{Kejelasan Tujuan Anggaran}

Kejelasan tujuan anggaran menunjukkan luasnya tujuan anggaran yang dinyatakan secara spesifik dan jelas, dan dimengerti oleh siapa saja yang bertanggung jawab.

Kenis (1979) menemukan bahwa manajer memberi reaksi positif dan secara relatif sangat kuat untuk meningkatkan kejelasan tujuan anggaran. Manajemen tingkat atas dapat 
meningkatkan kepuasan kerja, menurunkan ketegangan kerja, dan memperbaiki anggaran yang dihubungkan dengan sikap, kinerja anggaran, dan efisiensi biaya manajer tingkat bawah secara signifikan meningkatkan kejelasan dan ketegasan tujuan anggaran mereka.

Maryanti (2002) menemukan bahwa aparat pemerintah daerah dapat mengetahui hasil usahanya melalui evaluasi yang dilakukan secara efektif untuk mengetahui kejelasan tujuan anggaran dibuatnya dan mereka merasa puas bahwa anggaran yang dibuatnya adalah bermanfaat bagi kepentingan masyarakat.

\subsubsection{Umpan Balik Anggaran}

Kenis (1979) menemukan hanya kepuasan kerja dan motivasi anggaran ditemukan signifikan dengan hubungan yang agak lemah dengan umpan balik anggaran. Umpan balik mengenai tingkat pencapaian tujuan anggaran tidak efektif dalam memperbaiki kinerja dan hanya efektif secara marginal dalam memperbaiki sikap manajer. Penemuan ini gagal untuk menjelaskan hasil dari berbagai studi dengan hubungan umpan balik sikap, kinerja dalam task-goal setting.

Maryanti (2002) menemukan bahwa umpan balik mempunyai pengaruh positif terhadap perilaku dan sikap. Hal ini menunjukkan aparat pemerintah daerah mengetahui hasil usahanya dalam menyusun anggaran maupun dalam melaksanakan anggaran sehingga membuat mereka merasa sukses.

\subsubsection{Evaluasi Anggaran}

Evaluasi anggaran menunjuk pada luasnya perbedaan anggaran yang digunakan kembali oleh individu pimpinan departemen dan digunakan dalam evaluasi kinerja mereka.

Penemuan Kenis (1979) adalah bahwa manajer memberi reaksi yang tidak menguntungkan untuk menggunakan anggaran dalam evaluasi kinerja dalam suatu gaya punitive (meningkatkan ketegangan kerja, menurunkan kinerja anggaran. Kecenderungannya, secara jelas hubungan antara variabel lemah.

Maryanti (2002) menemukan bahwa evaluasi anggaran berpengaruh terhadap perilaku aparat pemerintah daerah. Hal ini menunjukkan bahwa dalam menyiapkan anggaran mereka selalu melakukan evaluasi kegiatan-kegiatan yang telah diprogramkan, namun pada saat pelaksanaan mereka tidak melakukan evaluasi terhadap kegiatan yang telah dilakukan sehingga membuat kinerja mereka menjadi rendah.

\subsubsection{Kesulitan Tujuan Anggaran}

Tujuan anggaran adalah range dari "sangat longgar dan mudah dicapai" sampai "sangat ketat dan tidak dapat dicapai". Tujuan yang mudah dicapai gagal untuk memberikan suatu tantangan untuk partisipan, dan memiliki sedikit pengaruh motivasi. Tujuan yang sangat ketat dan tidak dapat dicapai, mengarahkan pada perasaan gagal, frustrasi, tingkat aspirasi yang rendah, dan tujuan partisipan.

Kenis (1979) dalam manajer yang memiliki tujuan anggaran yang "terlalu ketat" secara signifikan memiliki ketegangan kerja tinggi dan motivasi kerja rendah, kinerja anggaran, dan efisiensi biaya dibandingkan untuk anggaran memiliki tujuan anggaran "tepat" atau "ketat tetapi dapat dicapai". Hal ini mengindikasikan bahwa "ketat tetapi dapat dicapai" adalah tingkat untuk kesulitan tujuan anggaran.

Maryanti (2002) menemukan bahwa aparat pemerintah daerah tidak dipengaruhi oleh kesulitan tujuan anggaran, sehingga dalam mempersiapkan penyusunan anggaran tidak terlalu memperhatikan mudah atau sulitnya anggaran yang dicapai.

\subsubsection{Peranan Anggaran Terhadap Perilaku}

Sesungguhnya perilaku terjadi karena suatu determinan tertentu. Determinan ini bisa dari lingkungan, dari dalam diri individu dan dari tujuan/nilai suatu obyek. Jika dikaitkan dengan anggaran, maka perilaku itu muncul disebabkan tujuan atau nilai suatu obyek anggaran tersebut. Perilaku ini dapat dilihat dari dua sisi yang berbeda yaitu sisi fungsional atau positif dan sisi disfungsional atau negatif.

Maryanti (2002) menemukan bahwa kejelasan tujuan anggaran, umpan balik anggaran, dan evaluasi anggaran memiliki pengaruh yang signifikan dan positif terhadap perilaku aparat 
pemerintah daerah. Hal ini menunjukkan bahwa kejelasan tujuan anggaran, umpan balik anggaran, dan evaluasi anggaran memiliki pengaruh terhadap perilaku aparat pemerintah daerah. Ini berarti evaluasi yang dilakukan oleh aparat pemerintah daerah adalah efektif, sehingga mereka dapat mengetahui hasil usahanya, dan membuat mereka merasa sukses dengan rencana anggaran yang dibuatnya. Namun di sisi lain partisipasi dalam penyusunan anggaran tidak menunjukkan hal yang positif dari perilaku aparatur pemerintah daerah.

\subsubsection{Pengaruh Anggaran Terhadap Sikap}

Maryanti (2002) menemukan bahwa umpan balik anggaran dan kejelasan tujuan anggaran memiliki pengaruh yang signifikan dan positif terhadap sikap, aparat pemerintah daerah. Hal ini menunjukkan bahwa aparat pemerintah daerah dapat mengetahui hasil usahanya sehingga membuat mereka merasa sukses. Untuk kejelasan tujuan anggaran berpengaruh secara signifikan dan negatif terhadap sikap, menunjukkan bahwa positif atau negatifnya sikap aparat pemerintah daerah tidak berpengaruh terhadap partisipasi anggaran,

Sikap ini akan mempengaruhi interpretasi individu mengenai kebijakan, aturan, gaya manajerial, dan peristiwa organisasi lainnya. Interpretasi ini menentukan perilaku individu, yang konsekuensinya adalah semua aparat pemerintah daerah tidak memberikan reaksi dalam cara yang sama di saat penetapan anggaran di masing-masing unit kerjanya.

\subsubsection{Peranan Anggaran Dalam Pengukuran Kinerja}

Michael, dan Troy (2000) menjelas-kan untuk mengukur kinerja sebuah pemerintah lokal dalam perbandingannya dengan tujuan-tujuan yang telah ditetapkan maka diperlukan akuntabel oleh pemerintah lokal. Namun yang tidak kalah pentingnya adalah para pembuat kebijakan dan profesional harus merumuskan visi dan tujuan dari rencana strategis mereka dengan menggunakan input dari masyarakat/publik. Jika input dari masyarakat ini tidak di akomodasi maka akan mengundang kritikan, walaupun pemerintahan lokal sudah melaksanakan secara efisien sekalipun.

Maryanti (2002) menemukan bahwa partisipasi anggaran, kejelasan tujuan anggaran, umpan balik anggaran, evaluasi anggaran, dan kesulitan tujuan anggaran, tidak berpengaruh terhadap kinerja aparatur pemerintah daerah. Hal ini menunjukkan bahwa anggaran yang dibuat oleh aparat pemerintah daerah adalah tidak spesifik dan tidak jelas yang membuat kinerja aparat pemerintah daerah menjadi rendah.

Pengukuran kinerja tentunya tidak sebatas pada masalah pemakaian anggaran, namun lebih dari itu. Pengukuran kinerja mencakup berbagai aspek sehingga dapat memberikan informasi yang efisien dan efektif dalam pencapaian kinerja tersebut. Sesuai dengan pendekatan kinerja yang digunakan dalam penyusunan anggaran, maka setiap alokasi biaya yang direncanakan harus dikaitkan dengan tingkat pelayanan atau hasil yang diharapkan dapat dicapai. Kinerja pemerintah daerah dapat diukur melalui evaluasi terhadap pelaksanaan anggaran (Kepmendagri No 29 Tahun 2002).

\section{METODE PENELITIAN}

\subsection{Hipotesis}

H1: Karakteristik tujuan anggaran berpengaruh positif terhadap perilaku aparat pemerintah

H2: Karakteristik tujuan anggaran berpengaruh positif terhadap sikap aparat pemerintah

H3: Karakteristik tujuan anggaran berpengaruh positif terhadap kinerja aparat pemerintah 


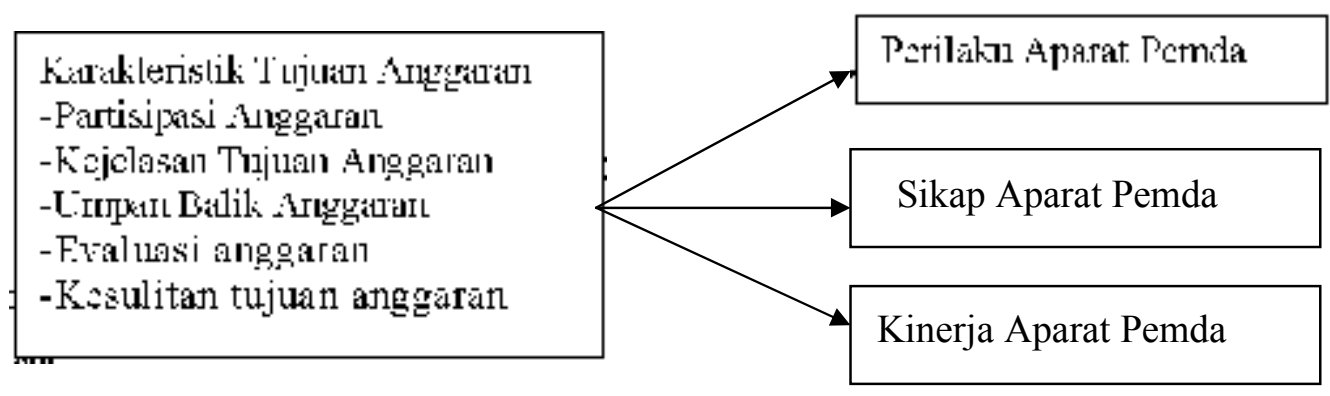

\subsection{Pendekatan Penelitian}

Penelitian ini menggunakan dua pendekatan yaitu Pendekatan Kuantitatif dan Pendekatan Kualitatif. Pendekatan Kuantitatif yang dilakukan adalah penelitian penjelasan (Explanatory Research) yang berguna untuk menganalisis bagaimana suatu variabel mempengaruhi variabel lain melalui pengujian hipotesis dan bersifat extended replication. Pendekatan kualitatif dalam penelitian ini menggunakan metode kombinasi (triangulation) yaitu menawarkan kesempatan untuk meningkatkan kesahihan data sehingga menghasilkan satu kesatuan yaitu hasil yang didapat dalam metode kuantitatif akan dapat dilengkapi dari hasil yang diperoleh dengan metode kualitatif (Bryman, 1990 seperti yang dikutip oleh Brannen, 1996).

\subsection{Populasi dan Teknik Pengambilan Data}

Populasi dalam penelitian ini adalah aparat pemerintah daerah yang ada di bawah Sekretaris Daerah Kabupaten Minahasa yaitu Dinas, Badan, Kantor dan Kepala Bagian pada kantor Sekretaris Daerah. Jumlah populasi terdiri atas Dinas sebanyak 14 responden, Badan sebanyak 7 responden, kantor sebanyak 1 responden, dan kepala bagian sebanyak 13 responden sehingga total responden yang diteliti sebanyak 34 responden. Untuk mendapatkan data dibuatkan kuesioner dalam bentuk pertanyaan-pertanyaan secara berstruktur yang mana responden dibatasi dalam memberikan jawaban pada alternatif jawaban tertentu saja. Penelitian ini menggunakan lima variabel independen dan tiga variabel dependen dengan menggunakan skala Likert lima poin.

\subsection{Teknik Analisis Data.}

Pengujian hipotesis dalam penelitian ini menggunakan statistik non-parametrik untuk menguji hipotesis $\mathrm{H}_{1}, \mathrm{H}_{2}$, dan $\mathrm{H}_{3}$ oleh karena itu setiap data konstruk variabel harus terlebih dahulu diuji normalitasnya. Dalam penelitian ini digunakan tingkat signifikansi $(\alpha) 0,05$ atau $5 \%$ untuk menguji apakah hipotesis yang diajukan dalam penelitian ini diterima atau ditolak dilakukan dengan cara menguji nilai $F$. Untuk menguji masing-masing variabel independen secara parsial terhadap dependen dilakukan dengan menguji nilai t dengan uji dua sisi pada tingkat signifikansi $(\alpha) 0,05$ atau $5 \%$.

Pengujian hipotesis dalam penelitian ini menggunakan alat analisis regresi berganda. Adapun bentuk matematis analisis regresi berganda sebagai berikut:

$$
\begin{aligned}
& Y_{1}=a+b_{1} X_{1}+b_{2} X_{2}+b_{3} X_{3}+b_{4} X_{4}+b_{5} X_{5}+e \\
& Y_{2}=a+b_{1} X_{1}+b_{2} X_{2}+b_{3} X_{3}+b_{4} X_{4}+b_{5} X_{5}+e \\
& Y_{3}=a+b_{1} X_{1}+b_{2} X_{2}+b_{3} X_{3}+b_{4} X_{4}+b_{5} X_{5}+e
\end{aligned}
$$

Di mana :

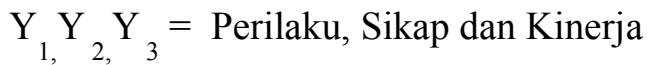

$\mathrm{X}_{1}=$ Partisipasi anggaran

$\mathrm{X}_{2}=$ Kejelasan tujuan anggaran 
$\mathrm{X}_{3}=$ Umpan balik anggaran

$\mathrm{X}_{4}=$ Evaluasi anggaran

$\mathrm{X}_{5}=$ Kesulitan tujuan anggaran

$\mathrm{a}=$ Konstanta

$\mathrm{b}=$ Koefesien regresi

\subsection{Analisis Kualitatif}

Analisis ini bukanlah merupakan kajian yang berdiri sendiri, tetapi merupakan bagian integral dari analisis sebelumnya yang menggunakan pendekatan statistik. Ini dilakukan dengan tujuan untuk memperoleh jawaban atas perumusan masalah sebelumnya.

Analisis kualitatif yang digunakan dalam penelitian ini adalah metode fenomenologi. Metode ini digunakan dengan cara melakukan pengamatan terhadap partisipan (aparat pemerintah daerah yang berkompeten dengan anggaran) yaitu dengan wawancara intensif agar mampu menyibak orientasi subjek dan selanjutnya akan melakukan interpretasi terhadap makna yang didapat dari aktivitas tersebut (Orleans:2000) seperti yang dikutip oleh Basrowi :2002).

\section{HASIL DAN PEMBAHASAN}

\subsection{Pengujian Hipotesis Pertama (H 1) dan Telaah Kualitatif}

Hasil analisis dari variabel karakteristik tujuan anggaran yang meliputi partisipasi anggaran $\left(\mathrm{X}_{1}\right)$, kejelasan tujuan anggaran $\left(\mathrm{X}_{2}\right)$, umpan balik anggaran $\left(\mathrm{X}_{3}\right)$, evaluasi anggaran $\left(\mathrm{X}_{4}\right)$, dan kesulitan tujuan anggaran $\left(\mathrm{X}_{5}\right)$ dengan variabel perilaku $\left(\mathrm{Y}_{1}\right)$ sebagai berikut:

Tabel 1 Hasil Analisis Regresi

\begin{tabular}{|c|c|c|c|c|}
\hline Variabel & $\begin{array}{l}\text { Unstandardized Coefficients } \\
\text { (B) }\end{array}$ & $\begin{array}{c}\mathrm{T} \\
\text { hitung }\end{array}$ & Sig. & Ket. \\
\hline Constant & 27.202 & & & \\
\hline $\mathrm{PA}\left(\mathrm{X}_{1}\right)$ & 0.440 & 2.627 & 0.014 & Sig \\
\hline $\operatorname{KTA}\left(\mathrm{X}_{2}\right)$ & 0.585 & 2.308 & 0.029 & Sig \\
\hline $\operatorname{UBA}\left(\mathrm{X}_{3}\right)$ & 0.309 & 2.283 & 0.030 & Sig \\
\hline $\mathrm{EA}\left(\mathrm{X}_{4}\right)$ & 0.002 & 0.012 & 0.990 & $\begin{array}{l}\text { Tdk } \\
\text { Sig }\end{array}$ \\
\hline $\operatorname{STA}\left(\mathrm{X}_{5}\right)$ & -0.807 & -2.387 & 0.024 & Sig \\
\hline $\begin{array}{l}\mathrm{R} \\
\mathrm{R} \text { Square } \\
\mathrm{F} \text { hitung } \\
\text { F tabel } \\
\text { Sigi. F } \\
\mid x\end{array}$ & & & $\begin{array}{l}= \\
= \\
= \\
= \\
= \\
=\end{array}$ & $\begin{array}{l}.800 \\
.641 \\
.989 \\
.493 \\
.000 \\
.05\end{array}$ \\
\hline
\end{tabular}

Model regresi berdasarkan hasil analisis di atas adalah :

$\mathrm{Y}=27.202+0.002 \mathrm{X} 1+0.585 \mathrm{X} 2+0.309 \mathrm{X} 3+0.440 \mathrm{X} 4-0.807 \mathrm{X} 5+\mathrm{e}$

Persamaan tersebut menunjukkan bahwa angka yang signifikan pada variabel karakteristik tujuan anggaran yang diwakili dari $\left(\mathrm{X}_{1}\right),\left(\mathrm{X}_{2}\right),\left(\mathrm{X}_{3}\right)$, dan $\left(\mathrm{X}_{5}\right)$ sedangkan variabel $\left(\mathrm{X}_{4}\right)$, tidak menunjukkan angka yang signifikan. 


\subsubsection{Pengujian Hipotesis Secara Simultan (Uji F)dan Telaah Kualitatif}

Tabel 2 Pengujian Hipotesis (Simultan)

\begin{tabular}{|c|l|l|c|}
\hline & \multicolumn{1}{|c|}{ Hipotesis Alternatif (Ha) } & \multicolumn{1}{c|}{ Nilai } & Status \\
\hline $1_{1}$ & Terdapat pengaruh yang signifikan secara & $\mathrm{F}=9.989$ & $\mathrm{Ha}$ \\
& $\begin{array}{l}\text { serentak dari Variabel Karakteristik tujuan } \\
\text { anggaran terhadap perilaku }\end{array}$ & $\begin{array}{c}\text { Sig F }=0.000 \\
\mathrm{~F}_{\text {tabel }}=2.493\end{array}$ & $\begin{array}{c}\text { tidak } \\
\text { ditolak } \\
\text { / Ho } \\
\text { ditolak }\end{array}$ \\
\hline
\end{tabular}

Berdasarkan tabel tersebut menunjukkan bahwa variabel karakteristik tujuan anggaran yang diwakili dari $\left(\mathrm{X}_{1}\right),\left(\mathrm{X}_{2}\right),\left(\mathrm{X}_{3}\right),\left(\mathrm{X}_{4}\right)$, dan $\left(\mathrm{X}_{5}\right)$ secara serentak berpengaruh terhadap perilaku. Pada pengujian ini $\mathrm{H}_{\mathrm{a}}$ tidak ditolak dengan ditunjukkan dengan besarnya $\mathrm{F}_{\text {hitung }}$ sebesar 9.989. Nilai ini lebih besar dari $\mathrm{F}_{\text {tabel }}(9.989>2.493)$.

Hasil penelitian ini secara simultan mendukung penelitian Maryanti (2002) yaitu karakteristik tujuan anggaran dengan variabel partisipasi anggaran, kejelasan tujuan anggaran, umpan balik anggaran, evaluasi anggaran, dan kesulitan tujuan anggaran berpengaruh secara signifikan terhadap perilaku. Hal ini menunjukkan bahwa karakteristik tujuan anggaran secara keseluruhan menghasilkan pengaruh yang cukup kuat terhadap perilaku aparat pemerintah daerah Kabupaten Minahasa dalam menyiapkan rencana penyusunan anggaran. Dengan demikian aparat pemerintah daerah Kabupaten Minahasa dalam menyiapkan rencana penyusunan anggaran satuan kerja (RASK) di masing-masing unit kerja yang nantinya akan dijadikan sebagai Rencana APBD Kabupaten Minahasa telah mengikuti sistem anggaran kinerja yaitu melalui partisipasi masyarakat yang dijaring melalui musyawarah rencana pembangunan tingkat dusun, desa, kecamatan dan tingkat kabupaten serta keterlibatan stafstaf mereka sebelum penyusunan anggaran. Dengan adanya penjaringan aspirasi masyarakat dan keterlibatan staf-staf dalam persiapan penyusunan anggaran, maka anggaran yang dibuat pada masing-masing unit kerja akan menjadi jelas tujuannya, mempunyai nilai manfaat bagi masyarakat, dapat dievaluasi dalam pelaksanaannya walaupun plafon anggaran pada masingmasing satuan unit kerja telah ditetapkan. Jadi dengan melalui tahapan-tahapan dalam penyusunan anggaran tersebut membuat aparat pemerintah daerah Kabupaten Minahasa akan mengetahui hasil usahanya sehingga membuat mereka merasa yakin dan sukses dengan rencana anggaran yang dibuatnya.

Hasil analisis kualitatif berdasarkan wawancara dengan beberapa informan menemukan bahwa karakteristik tujuan secara serentak berpengaruh signifikan terhadap perilaku aparat pemerintah daerah Kabupaten Minahasa dapat dibuktikan.

\subsubsection{Pengujian Hipotesis Secara Parsial (Uji t) dan Telaah Kulitatif}

Berdasarkan hasil pengujian parsial (uji t) yaitu karakteristik tujuan anggaran yang diwakili oleh variabel $\left(\mathrm{X}_{1}\right),\left(\mathrm{X}_{2}\right),\left(\mathrm{X}_{3}\right),\left(\mathrm{X}_{4}\right)$, dan $\left(\mathrm{X}_{5}\right)$ terhadap perilaku, secara parsial hanya variabel $\left(X_{1}\right),\left(X_{2}\right),\left(X_{3}\right),\left(X_{5}\right)$ yang berpengaruh secara signifikan terhadap perilaku, sedangkan $\left(\mathrm{X}_{4}\right)$ tidak berpengaruh secara signifikan terhadap perilaku. Hal ini menunjukkan bahwa perilaku aparat pemerintah daerah dalam menyusun rencana anggaran satuan kerja (RASK) pada masing-masing unit kerja telah mengikuti sistem anggaran kinerja. Dalam sistem anggaran kinerja ini lebih mengutamakan upaya pencapaian hasil kerja atau ouput dari perencanaan alokasi biaya atau input yang ditetapkan. Selain itu semakin tinggi partisipasi 
masyarakat dan staf-staf pada masing-masing unit kerja ikut terlibat dalam penyusunan anggaran maka, semakin baik pula perilaku aparat pemerintah daerah.

Berdasarkan hasil ujian hipotesis secara parsial (uji t) seperti yang di kemukakan di atas menunjukkan bahwa variabel evaluasi anggaran $\left(\mathrm{X}_{4}\right)$ tidak berpengaruh terhadap perilaku aparat pemerintah, ternyata pada telaahan kualitatif tidak terbukti. Hal ini dibuktikan dengan setelah disetujui RAPBD oleh DPRD menjadi APBD, maka kurang lebih 3 hari RAPBD selanjutnya harus disampaikan ke Gubernur untuk dievaluasi. Kurang lebih 15 hari RAPBD dievaluasi di Gubernur dan setelah itu dikembalikan ke pemerintah daerah untuk ditindak lanjuti bersama DPRD dengan mengeluarkan Peraturan Daerah tentang APBD. Setelah disahkan, maka APBD ini akan dijadikan dokumen anggaran satuan kerja (DASK).

\subsubsection{Pengujian Hipotesis Kedua (H2) dan Telaah Kualitatif}

Hasil analisis dari variabel karakteristik tujuan anggaran yang diwakili oleh variabel $\left(\mathrm{X}_{1}\right),\left(\mathrm{X}_{2}\right),\left(\mathrm{X}_{3}\right),\left(\mathrm{X}_{4}\right)$, dan $\left.\left(\mathrm{X}_{5}\right)\right)$ dengan variabel sikap $\left(\mathrm{Y}_{2}\right)$ sebagai berikut:

Tabel 3 Hasil Analisis Regresi

\begin{tabular}{|c|c|c|c|c|}
\hline Variabel & $\begin{array}{l}\text { Unstandardized } \\
\text { Coefficients (B) }\end{array}$ & T hitung & Sig. & Ket. \\
\hline Constant & 25.841 & & & \\
\hline $\mathrm{PA}\left(\mathrm{X}_{1}\right)$ & 0.479 & 2.385 & 0.024 & Sig \\
\hline$\overline{\mathrm{KTA}}\left(\mathrm{X}_{2}\right)$ & -0.054 & -0.177 & 0.861 & $\begin{array}{l}\text { Tdk } \\
\text { Sig }\end{array}$ \\
\hline UBA $\left(X_{3}\right)$ & 0.369 & 2.271 & 0.031 & Sig \\
\hline$\overline{E A}\left(X_{4}\right)$ & -0.149 & -0.769 & 0.448 & $\begin{array}{l}\text { Tdk } \\
\text { Sig }\end{array}$ \\
\hline $\operatorname{STA}\left(\mathrm{X}_{5}\right)$ & 0.305 & 0.751 & 0.459 & $\begin{array}{l}\text { Tdk } \\
\text { Sig }\end{array}$ \\
\hline $\begin{array}{l}\mathrm{R} \\
\text { R Square } \\
\text { F hitung } \\
\text { F tabel } \\
\text { Sign. F } \\
a\end{array}$ & & & & $\begin{array}{l}= \\
0.622 \\
= \\
0.387 \\
= \\
3.543 \\
= \\
2.493 \\
= \\
0.013 \\
=0.05 \\
\end{array}$ \\
\hline
\end{tabular}

Model regresi berdasarkan hasil analisis di atas adalah

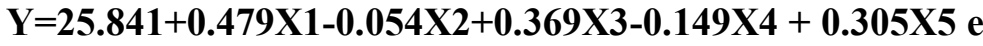

Tampak pada persamaan tersebut angka yang signifikan terhadap sikap adalah pada variabel $\left(\mathrm{X}_{1}\right),\left(\mathrm{X}_{3}\right)$, sedangkan $\left(\mathrm{X}_{2}\right),\left(\mathrm{X}_{4}\right)$, dan $\left(\mathrm{X}_{5}\right)$ tidak menunjukkan angka yang signifikan. 


\subsubsection{Pengujian Hipotesis Secara Simultan (Uji F) dan Telaah Kulitatif Pengujian Hipotesis (Simultan)}

Tabel 4

\begin{tabular}{|c|l|l|c|}
\hline & \multicolumn{1}{|c|}{ Hipotesis Alternatif $(\mathrm{Ha})$} & \multicolumn{1}{c|}{ Nilai } & Keterangan \\
\hline $2_{1}$ & Terdapat pengaruh yang signifikan & $\mathrm{F}=$ & Ha tidak \\
& secara serentak dari Variabel & 3.543 & ditolak \\
& Karakteristik tujuan anggaran & $\mathrm{Sig} \mathrm{F}=$ & $/$ Ho \\
& terhadap sikap & 0.013 & ditolak \\
& & $\mathrm{F}_{\text {tabel }}=$ & \\
& & 2.493 & \\
\hline
\end{tabular}

Tabel di atas menunjukkan bahwa karakteristik tujuan anggaran yang diwakili oleh variabel $\left(X_{1}\right),\left(X_{2}\right),\left(X_{3}\right),\left(X_{4}\right)$, dan $\left(X_{5}\right)$ secara serentak berpengaruh terhadap sikap. Pada pengujian ini $\mathrm{H}_{\mathrm{a}}$ tidak ditolak dengan ditunjukkan $\mathrm{F}_{\text {hitung }}$ sebesar 3.543. Nilai ini lebih besar dari $\mathrm{F}_{\text {tabel }}(3.543>2.493)$.

Hasil penelitian ini mendukung hasil penelitian Maryanti (2002) yang menemukan bahwa secara simultan terdapat pengaruh yang cukup signifikan dari karakteristik tujuan anggaran terhadap sikap. Hal ini menunjukkan bahwa karakteristik tujuan anggaran secara keseluruhan menghasilkan pengaruh cukup kuat terhadap sikap aparat pemerintah daerah Kabupaten Minahasa dalam melaksanakan anggaran. Selain itu aparat pemerintah daerah Kabupaten Minahasa menunjukkan sikap yang positif terhadap anggaran yang telah di tetapkan pemerintah daerah bersama DPRD Kabupaten Minahasa yaitu APBD (dalam bentuk dokumen anggaran satuan kerja (DASK) bagi masing-masing unit kerja dan dilaksanakan sesuai dengan tujuan anggaran yang telah ditetapkan. Hal ini dibuktikan dengan aparat pemerintah daerah Kabupaten Minahasa turut berpartisipasi dalam pelaksanaan anggaran sesuai dengan tujuan anggaran yang telah ditetapkan dan dapat mengetahui hasil usahanya sehingga mereka merasa sukses di dalam melaksanakan anggaran pada unit kerjanya.

\subsubsection{Pengujian Hipotesis Ketiga (H 3) dan Telaah Kualitatif}

Dalam mencari hubungan antara variabel independen dan variabel dependen, melalui hubungan variabel karakteristik tujuan anggaran yang diwakili oleh variabel $\left(\mathrm{X}_{1}\right),\left(\mathrm{X}_{2}\right),\left(\mathrm{X}_{3}\right)$, $\left(\mathrm{X}_{4}\right)$, dan $\left(\mathrm{X}_{5}\right)$ ) dengan Kinerja $\left(\mathrm{Y}_{3}\right)$ adalah sebagai berikut:

Tabel 5 Hasil Analisis Regresi

\begin{tabular}{|l|c|c|c|l|}
\hline \multicolumn{1}{|c|}{ Variabel } & $\begin{array}{l}\text { Unstandardized } \\
\text { Coefficients (B) }\end{array}$ & T hitung & Sig. & Ket. \\
\hline \multicolumn{1}{|c|}{ Constant } & 67.517 & & & \\
\hline PA $\left(\mathrm{X}_{1}\right)$ & 1.034 & 2.385 & 0.024 & Sig \\
\hline KTA $\left(\mathrm{X}_{2}\right)$ & 0.526 & 0.801 & 0.430 & Tdk Sig \\
\hline UBA $\left(\mathrm{X}_{3}\right)$ & 1.227 & 3.501 & 0.002 & Sig \\
\hline $\mathrm{EA}\left(\mathrm{X}_{4}\right)$ & -0.158 & -0.377 & 0.709 & Tdk Sig \\
\hline $\mathrm{STA}\left(\mathrm{X}_{5}\right)$ & 0.612 & 0.698 & 0.491 & Tdk Sig \\
\hline
\end{tabular}




\begin{tabular}{|ll|}
\hline R & $=0.747$ \\
R Square & $=0.559$ \\
F hitung & $=7.087$ \\
F tabel & $=2.493$ \\
Sign. F & $=0.000$ \\
$x$ & $=0.05$ \\
\hline
\end{tabular}

Model regresi berdasarkan hasil analisis di atas adalah

$Y=67.517+1.034 X 1+0.526 \times 2+1.227 X 3-0.158 X 4+0.612 X 5+e$

Tampak pada persamaan tersebut menunjukkan angka yang signifikan pada variabel $\left(\mathrm{X}_{1}\right)$ dan $\left(\mathrm{X}_{3}\right)$ sedangkan variabel yang lain yaitu $\left.\mathrm{X}_{2}\right),\left(\mathrm{X}_{4}\right)$, dan $\left(\mathrm{X}_{5}\right)$ tidak menunjukkan angka yang signifikan.

\subsubsection{Pengujian Hipotesis Secara Simultan (Uji F) dan Telaah Kualitatif}

Tabel 6 Pengujian Hipotesis (Simultan)

\begin{tabular}{|l|l|l|c|}
\hline & \multicolumn{1}{|c|}{ Hipotesis Alternatif (Ha) } & \multicolumn{1}{c|}{ Nilai } & Status \\
\hline $2_{1}$ & Terdapat pengaruh yang signifikan secara & F $=$ & Ha tidak \\
& serentak dari Variabel Karakteristik tujuan & 7.087 & ditolak \\
& anggaran terhadap kinerja & Sig F $=$ & / Ho ditolak \\
& & 0.000 & \\
& & $\mathrm{~F}_{\text {tabel }}=$ & \\
& & 2.493 & \\
\hline
\end{tabular}

Tabel di atas menunjukkan bahwa variabel karakteristik tujuan anggaran yang diwakili oleh variabel $\left(\mathrm{X}_{1}\right),\left(\mathrm{X}_{2}\right),\left(\mathrm{X}_{3}\right),\left(\mathrm{X}_{4}\right)$, dan $\left(\mathrm{X}_{5}\right)$ ) secara serentak berpengaruh terhadap kinerja. Pada pengujian ini $\mathrm{H}_{\mathrm{a}}$ tidak ditolak yang ditunjukkan dengan besarnya $\mathrm{F}_{\text {hitung }}$ sebesar 7.087. Nilai ini lebih besar dari $\mathrm{F}_{\text {tabel }}(7.087>2.493)$. Hal ini menunjukkan bahwa terdapat pengaruh yang cukup signifikan dari variabel yang diwakili oleh variabel $\left(X_{1}\right),\left(X_{2}\right),\left(X_{3}\right),\left(X_{4}\right)$, dan $\left(\mathrm{X}_{5}\right)$ ) terhadap kinerja.

Hasil pengujian hipotesis menunjukkan bahwa penelitian ini tidak mendukung hasil penelitian Maryanti (2002) yang menyatakan bahwa karakteristik tujuan anggaran yang diwakili oleh variabel partisipasi anggaran, kejelasan tujuan anggaran, umpan balik anggaran, evaluasi anggaran, dan kesulitan tujuan anggaran tidak berpengaruh secara serentak terhadap Kinerja. Hasil penelitian ini menunjukkan bahwa karakteristik tujuan anggaran yang diwakili oleh variabel partisipasi anggaran, kejelasan tujuan anggaran, umpan balik anggaran, evaluasi anggaran, dan kesulitan tujuan anggaran berpengaruh secara serentak terhadap Kinerja. Hal ini terbukti bahwa karakteristik tujuan anggaran secara keseluruhan menghasilkan pengaruh cukup kuat terhadap kinerja aparat pemerintah daerah, karena semakin baik aparat pemerintah daerah Kabupaten Minahasa turut berpartisipasi dalam menyusun rencana anggaran, melaksanakan anggaran dan menilai sendiri tentang pencapaian anggaran yang telah di tetapkan maka semakin baik kinerjanya.

\subsubsection{Pengujian Hipotesis Secara Parsial (Uji t) dan Telaah Kualitatif}

Secara parsial hanya variabel $\left(\mathrm{X}_{1}\right)$ dan $\left(\mathrm{X}_{3}\right)$ yang berpengaruh secara signifikan terhadap kinerja, sedangkan variabel yang lain $\left(\mathrm{X}_{2}\right),\left(\mathrm{X}_{4}\right)$, dan $\left(\mathrm{X}_{5}\right)$ tidak berpengaruh secara signifikan terhadap kinerja. Hal ini menunjukkan bahwa semakin baik partisipasi aparat pemerintah daerah Kabupaten Minahasa dalam menyusun anggaran, melaksanakan anggaran, 
dan mempertanggungjawabkan anggaran sesuai dengan arah kebijakan umum, strategik dan prioritas APBD, visi, misi, tujuan pokok dan fungsi instansi, serta sasaran dan tujuan dari masing-masing instansi maka kinerjanya dianggap baik. Selanjutnya dalam melaksanakan anggaran aparat pemerintah daerah Kabupaten Minahasa mengetahui pula hasil usahanya (umpan balik) sehingga mereka merasa sukses.

Berdasarkan hasil ujian hipotesis secara parsial (uji t) seperti yang di kemukakan di atas menunjukkan bahwa variabel untuk variabel kejelasan tujuan anggaran $\left(\mathrm{X}_{2}\right)$, evaluasi anggaran $\left(\mathrm{X}_{4}\right)$, dan kesulitan tujuan anggaran $\left(\mathrm{X}_{5}\right)$ pada ujian statistiknya (uji $\mathrm{t}$ ) menunjukkan tidak berpengaruh terhadap kinerja aparat pemerintah daerah Kabupaten Minahasa, ternyata pada telaahan kualitatif tidak terbukti.

Anggaran yang telah dilaksanakan oleh masing-masing unit kerja, maka pada setiap bulannya akan dilakukan pertanggung jawaban. Kegiatan ini dilakukan dengan maksud untuk mengetahui sejauh mana penggunaan anggaran dari setiap program dan kegiatan dari masingmasing unit kerja agar anggaran tersebut benar-benar harus sesuai dengan tujuan anggaran yang telah ditetapkan.

\section{Kesimpulan, Keterbatasan dan Saran \\ 5.1. Kesimpulan}

Berdasarkan hasil pembahasan yang telah di kemukakan sebelumnya, maka dapat disimpulkan hal-hal sebagai berikut :

1. Hasil penelitian ini secara simultan mendukung penelitian Maryanti (2002) yaitu karakteristik tujuan anggaran berpengaruh secara signifikan terhadap perilaku. Hal ini menunjukkan bahwa karakteristik tujuan anggaran secara keseluruhan menghasilkan pengaruh yang cukup kuat terhadap perilaku aparat pemerintah daerah kabupaten Minahasa dalam rencana penyusunan anggaran. Hasil kesimpulan analisis statistik uji f yang di kemukakan di atas dapat didukung oleh telaahan kualitatif. Hal ini dibuktikan dengan perilaku aparat pemerintah daerah kabupaten Minahasa dalam menyusun rencana anggaran pada masing-masing unit kerja telah mengikutsertakan staf-staf, penjaringan aspirasi masyarakat melalui musyawarah sebelum anggaran pada unit kerja di buat. Namun secara parsial (Uji t) hasil telaahan kualitatif tidak mendukung hasil analisis kuantitatif (analisis statistik). Hal ini dibuktikan dengan variabel evaluasi anggaran pada analisis statistik tidak berpengaruh secara signifikan terhadap perilaku, namun pengungkapan secara mendalam pada telaahan kualitatif ternyata hasil analisisnya mendukung variabel evaluasi anggaran cukup kuat terhadap perilaku aparat pemerintah daerah dalam menyusun anggaran.

2. Hasil penelitian ini mendukung hasil penelitian Maryanti (2002) yang membuktikan bahwa secara simultan terdapat pengaruh yang cukup signifikan dari karakteristik tujuan anggaran terhadap sikap. Hal ini menunjukkan bahwa karakteristik tujuan anggaran secara keseluruhan menghasilkan pengaruh cukup kuat terhadap sikap aparat pemerintah daerah Kabupaten Minahasa dalam melaksanakan anggaran. Hasil kesimpulan analisis statistik (Uji F) yang di kemukakan di atas dapat didukung oleh telaahan kualitatif. Hal ini dibuktikan dengan telaahan kualitatif dari hasil wawancara beberapa informan mengindikasikan bahwa sikap aparat pemerintah daerah Kabupaten Minahasa adalah cukup positif dalam melaksanakan anggaran pada masing-masing unit kerja atas program dan kegiatan kerja yang terdapat dalam DASK-nya. Namun secara parsial (Uji t) hasil telaahan kualitatif tidak mendukung hasil analisis kuantitatif (analisis statistik). Hal ini dibuktikan dengan variabel kejelasan tujuan anggaran, evaluasi anggaran, dan kesulitan tujuan anggaran pada analisis statistik tidak berpengaruh secara signifikan terhadap sikap, namun pengungkapan secara mendalam pada telaahan kualitatif ternyata hasil analisisnya mendukung variabel kejelasan tujuan anggaran, evaluasi anggaran, dan kesulitan tujuan anggaran adalah cukup positif terhadap sikap aparat pemerintah daerah dalam melaksanakan anggaran. 
3. Penelitian ini tidak mendukung hasil penelitian Maryanti (2002) yang menyatakan bahwa karakteristik tujuan anggaran tidak berpengaruh secara serentak terhadap Kinerja. Namun penelitian ini membuktikan bahwa karakteristik tujuan anggaran berpengaruh secara serentak terhadap Kinerja. Hal ini menunjukkan bahwa karakteristik tujuan anggaran secara keseluruhan menghasilkan pengaruh cukup kuat terhadap kinerja aparat pemerintah daerah, karena semakin baik aparat pemerintah daerah Kabupaten Minahasa turut berpartisipasi dalam menyusun rencana anggaran, melaksanakan anggaran dan menilai sendiri tentang pencapaian anggaran yang telah di tetapkan maka semakin baik kinerjanya. Hasil analisis kualitatif yang menggunakan wawancara atas beberapa informan mengindikasikan bahwa kinerja aparat pemerintah daerah kabupaten Minahasa adalah cukup positif dalam mempertanggungjawabkan DASK yang dilaksanakan. Hal ini dibuktikan dengan partisipasi aparat pemerintah daerah kabupaten Minahasa dalam mempertanggung jawabkan anggarannya dalam bentuk SPJ yang tidak mengalami kesulitan bagi pihak verifikasi, sehingga tiap bulan unit kerja dapat mengajukan SPP pada bulan berikut. Dalam hal pengukuran kinerja aparat pemerintah kabupaten Minahasa bukan dilihat dari keberhasilan dalam pelaksanaan anggaran, akan tetapi masih banyak aspek lain yang dinilai dan penilaiannya langsung oleh atasan langsung atau Bupati. Namun secara parsial ( Uji t ) hasil telaahan kualitatif tidak mendukung hasil analisis kuantitatif (analisis statistik). Hal ini dibuktikan dengan variabel kejelasan tujuan anggaran, evaluasi anggaran, dan kesulitan tujuan anggaran pada analisis statistik tidak berpengaruh secara signifikan terhadap kinerja, akan tetapi setelah diadakan pengungkapan secara mendalam pada telaahan kualitatif ternyata hasil analisisnya mendukung variabel kejelasan tujuan anggaran, evaluasi anggaran, dan kesulitan tujuan anggaran adalah cukup positif terhadap kinerja aparat pemerintah daerah dalam mempertanggung jawabkan anggaran.

4. Penelitian ini mengungkapkan bahwa pada analisis kuantitatif (uji statistik) dengan variabel karakteristik tujuan anggaran terhadap perilaku, sikap, dan kinerja aparat pemerintah daerah Kabupaten Minahasa ternyata sebatas pada pengujian hipotesis saja, sehingga hasil yang didapat dari ujian tersebut hanya di permukaan saja yaitu dengan melihat hubungan antara variabel independen dengan variabel dependen. Selain itu hasil ujian statistik ini telah dibatasi oleh standar tertentu seperti uji $\mathrm{F}$ dengan kriteria ditunjukkan dengan besarnya $\mathrm{F}_{\text {hitung }}$ lebih besar dari $\mathrm{F}_{\text {tabel }}$ maka hipotesis tersebut diterima atau sebaliknya. Pada telaahan kualitatif dengan variabel karakteristik tujuan anggaran terhadap perilaku, sikap, dan kinerja aparat pemerintah daerah Kabupaten Minahasa ternyata tidak terbatas. Hal ini dibuktikan dengan hasil pengungkapan yang mendalam dari telaahan kualitatif ternyata hasil analisis statistik (uji hipotesis) yang menguji variabel independen dengan variabel dependen hasilnya tidak saling berpengaruh, namun pada telaahan kualitatif ternyata tidak terbukti. Dengan demikian telaahan kualitatif dalam melihat variabel-variabel yang diteliti yaitu karakteristik tujuan anggaran terhadap perilaku, sikap, dan kinerja aparat pemerintah daerah Kabupaten Minahasa tidak hanya dilihat pada batasan tertentu, tetapi juga harus dilihat dibalik dari batasan itu, karena dibalik batasan itu tidak bebas dari nilai.

\subsection{Keterbatasan}

Penelitian ini hanya melihat variabel-variabel karakteristik tujuan anggaran sebagai variabel independen dan variabel perilaku, sikap, dan kinerja sebagai variabel dependen dalam menguji keterlibatan aparat pemerintah daerah Kabupaten Minahasa baik dalam penyusunan anggaran, melaksanakan anggaran maupun dalam mempertanggungjawabkan anggaran. Untuk itu dalam penelitian selanjutnya disarankan untuk dikembangkan dengan pertautan antarvariabel yang bersifat interaksi, serta memosisikan variabel tertentu seperti variabel motivasi sebagai variabel moderating maupun sebagai variabel intervening 


\section{3. saran}

Agar memberikan tambahan informasi dan menimbulkan inisiatif untuk melakukan penelitian pada masa akan datang yang menjadi salah satu sumber dalam pengembangan Ilmu Akuntansi khususnya Akuntansi Sektor Publik dan difokuskan pada bidang anggaran, maka pada saat pengambilan data sebaiknya di saat pemerintah daerah sedang menyusun anggaran.

\section{DAFTAR PUSTAKA}

Aimee, F.,dan Carol E., (2004), Aligning Priorities In Local Budgeting Processes. Journal of Public Budgeting, Accounting \& Financial Management . Boca Raton Summer 2004 Vol. 16, Iss.2; pg 210, 18 pgs.

Basrowi, S. (2002), Metode Penelitian Kualitatif Perspektif Mikro, Edisi Pertama. Penerbit Insan Cendekia, Surabaya.

Bryman, A. (1990), Quantity and Quality in Social Science Reseach. London: Unwin/Heineman

Dhammika, D., (2001), Legislative Bargaining and Incremental Budgeting. Economics Program Research School of Social Sciences. Australia National University Canberra, August 2001: 13-23

Kenis, I., (1979), Effects of Budgetary Goal Characteristics on Managerial Attitudes and Performance. The Accounting Review. LIV.2. Hal 707-721

Keputusan Menteri Dalam Negeri No. 29 Tahun 2002, Tentang Pedoman Pengurusan, Pertanggungjawaban dan Pengawasan Keuangan Daerah Serta Tata Cara Penyusunan APBD, Pelaksanaan Tata Usaha Keuangan Daerah dan Penyusunan Perhitungan APBD. Direktorat Pengelolaan Keuangan Daerah Direktorat Jenderal Otonomi Daerah, Jakarta

Maryanti, H., A., (2002), Pengaruh Karakteristik Tujuan Anggaran Terhadap Perilaku, Sikap, dan Kinerja Pemerintah Daerah Di Propinsi Nusa Tenggara Timur. (Tesis)

Michael, W. S. dan Troy A. (2000) Finacial Performance Monitoring And Custumer Oriented Government: A Case Study. Journal of Public Budgeting Accounting \&Financial Management,12(1), 87-105.

Peraturan Pemerintah Republik Indonesia Nomor 58 Tahun 2005 Tentang Pengelolaan Keuangan Daerah. Lembaga Negara Republik Indonesia Tahun 2005 Nomor 40

Peraturan Pemerintah Republik Indonesia Nomor 58 Tahun 2005 Tentang Sistem Informasi Keuangan Daerah. Lembaga Negara Republik Indonesia Tahun 2005 Nomor 138

Undang-Undang RI Nomor 32 Tahun 2004 Tentang Pemerintahan Daerah. Direktorat Jenderal Otonomi Daerah, Jakarta

Undang-Undang Republik Indonesia Nomor 33 Tahun 2004 tentang Perimbangan Keuangan Antara Pemerintah Pusat Dan Pemerintahan Daerah. Direktorat Jenderal Otonomi Daerah, Jakarta 